\title{
The legal regime of competition in India
}

\author{
Ovidiu-Horia MAICAN \\ Bucharest University of Economic Studies, Bucharest, Romania \\ ovidium716@gmail.com
}

\begin{abstract}
The study of the competition legislation in India has as justification the fact that the indian economy has one of the biggest growth rates in the world, India being the biggest democracy in the world.

At the beginning, India had its own competition law, called the Monopolies and Restrictive Trade Practices Act 1969 (MRTP Act). After the initiation of economic liberalization in 1991, it became imperative to put in place a competition law regime that was more responsive to the economic realities of the nation and in accordance with international practices. In 2002, the Indian Parliament voted for a new law, Competition Act, to regulate business practices in India. The Competition Act has as its goal to regulate three types of conduct (anti-competitive agreements, abuse of a dominant position and combinations). The Competition Act was amended by the Competition (Amendment) Act in 2007 and 2009.

The Competition Act has also created a new enforcement body, the Competition Commission of India (CCI), which is responsible for the enforcement of the Competition Act.

According to the provisions of the Competition Act, is allowed to make an appeal to the Competition Appellate Tribunal (COMPAT) against the decisions of the CCI. A further appeal from the decision of the COMPAT may be submitted before the Supreme Court of India.

In the same, the Competition Act is taking into consideration its enforcement with the aid of mutual international support and enforcement networks across the world.
\end{abstract}

Keywords: India, Economic Liberalization, Competition, Competition Act, Competition Commission.

\section{Introduction}

India adopted an economic and financial reform called New Economic Policy (NEP) in 1991 which consisted of three core factors, Liberalisation, Privatisation and Globalisation (LPG). It led India to open up its economy and which in turn led to "Competition" in almost each and every area of the Indian economic system.

In the wake of LPG policy, the Monopolistic and Restrictive Trade Practices Act, 1969 (MRTPAct,1969) was not outfitted properly sufficient to address the competition environment of the Indian economic system. It was replaced in 2002 by the Competition Act. The Competition Act, 2002 has provided for the establishment of a regulatory body, the Competition Commission of India (CCI).

\section{General Aspects}

The competition policy and competition law are two different concepts (Singh \& Lohiya, 2018).

The competition policy consists of range of government insurance policies that have an effect on the functioning of the markets like competition law, change policy, industrial policy, disinvestment policy, Foreign Direct Investment policy, fiscal policy, labour policy etc.

The competition law is a means to put in force competition policy and stop anti-competitive practices through corporations and useless authorities interventions. Competition policy is a wider concept than competition law.

The foundation of competition policy in India is laid down in the Directive Principles of State Policy (DPSP) beneath Article 38 and 39 of the Constitution of India, 1950. The Article 38

DOI: $10.2478 /$ picbe-2021-0089

(C) 2021 0.-H. Maican, published by Sciendo.

This work is licensed under the Creative Commons Attribution 4.0 License. 
stipulates an obligation on the State to secure a social order for the merchandising of welfare of the people. (Singh \& Lohiya, 2018)

In India, the Competition Act, 2002, has four objectives (to stop practices having negative impact on competition,to promote and preserve competition in markets, to protect the pursuits of consumers and to make certain freedom of alternate carried on by using different members in markets, in India, and for things connected therewith or incidental thereto) (Singh \& Lohiya, 2018).

India's Competition Act, 2002, enacted to fulfill the twin targets of legislation of anticompetitive practices and give impact to the World Trade Organization (WTO) Agreements.

India's pursuit of globalization has resulted in elimination of controls and liberalization of the economy. A key step in India's march towards going through competition, from within the country and from international actors. is the inception of a competition regulation regime (Gupta, 2019).

Competition laws are delivered to modify the manner in which businesses are performed in India, so as to create a level taking part in area with tremendous competition in the market (Gupta, 2019).

The underlying intent for this statute is for companies to compete on merit, and not with the aid of anti-competitive agreements and/or conduct. Having stated that, however, it may additionally be mentioned that even although opposition legal guidelines can be used by companies as a sword to make certain 'level playing field' in the market, the intent of this especially new statute is no longer to make it less complicated for the weaker companies to survive in the market (Gupta, 2019).

The Competition Act, 2002 was once stalled through public activity litigation concerning certain issues regarding the Competition Commission of India, difficult the constitutional validity of the Act. The Supreme Court has recommended changes to be incorporated in the Act, before it can be enforceable. In the backdrop of Supreme Court ruling the Government then has proposed to amend the Competition Act, 2002 which inter alia led to bifurcating Competition Commission and a Competition Appellate Tribunal in 2007. This is supplemented by means of Ministry of Corporate Affairs, has issued a notification in 2009, whereby the most controversial the Monopolies and Restrictive Trade Practices Act, 1969 stands repealed and is replaced by the Competition Act, 2002, with effect from September 1, 2009 (Nomani and Rahman, 2013).

On December 10, 2012, the Indian government delivered the Competition (Amendment) Bill, 2012 in the parliament. This Bill aims to adjust certain provisions of the Act as well as insert some new provisions to meet the evolving wants of industry. The Bill nonetheless has to be debated and passed via two houses of the parliament earlier than it turns into law (Nomani \& Rahman, 2013).

The paradigmatic structure of rules of anti-competitive practices in India is ingrained under Section three of the Act. It prohibits agreements which restrict the production, supply, distribution, acquisition or manipulation of items or provision of services, which cause or are likely to motivate a considerable destructive impact on competition within India. Further Section 3(2) gives that any settlement in contravention of this provision shall be void.

The need of the provision is to be examined, it unifies out the accepted prohibition of any settlement having an "appreciable unfavourable effect on competition" ("AAEC") inside India. Agreements entered into between corporations or associations of enterprises, or men and women or associations of men and women or companies (including cartels) that directly or indirectly determine buy or sale prices; limit or manipulate production, supply, markets or technical development, investment or provision of services; without delay or in a roundabout way end result 
in bid rigging or collusive bidding; or share the market or supply of production with the aid of way of allocation of geographical place of markets or the kind of items or offerings or the quantity of clients in the market are presumed to have an damaging effect on competition and are considered to be per se illegal. There is a presumption that such agreements would have an appreciable adverse effect on competition: However, such presumption is now not applicable in case of any agreement entered into by way of way of joint ventures if such agreement increases effectivity in production, supply, distribution, storage, acquisition or manipulate of goods or provision of services (Nomani \& Rahman, 2013).

The framework of evaluation for identifying whether or not an agreement has an AAEC is unique for tough core "horizontal" agreements (between competing firms) and "vertical" agreements (between companies that are lively at one of a kind levels of an industry) and other "horizontal agreements". The Act states explicitly that egregious horizontal agreements., pricefixing, output restrictions, market-sharing, bid-rigging are presumed to provide upward jab to an AAEC. This strategy is in line with the extreme anti-cartel enforcement coverage of antitrust authorities world-wide. Other classes of horizontal agreements are analyzed under a "rule of reason", balancing the advantages springing up from the agreements towards the restrictions on competition (Nomani \& Rahman, 2013).

This applies also to joint ventures that can be confirmed to be efficiency-enhancing. These will no longer be presumed to give upward thrust to an AAEC - even if involving rivals and "hardcore" restrictions.

Section 3(4) offers vertical agreement. It lists, in particular, five classes of vertical agreements, namely, tie-in-agreement, different furnish agreement, one-of-a-kind distribution agreement; ,refusal to deal and resale for maintenance.. The approach for all vertical agreements is uniform: these are to be analyzed beneath a "rule of reason" in order to determine whether or not they supply upward shove to an AAEC. This softer cure acknowledges that verticals can have advisable aspects as well, and these need to be weighed towards the hazardous results to see if the settlement is on balance anti-competitive. The detrimental impact may additionally include restrictions on intra-brand competition, foreclosure of competition, and compartmentalization of markets, and the pro-competitive effects can consist of effectivity gains, make bigger in inter-brand competition, and preventing of free-riding (Nomani and Rahman, 2013).

Section 3 (5) provides exemption to the regular rule. The prohibition does no longer practice to "reasonable" prerequisites in agreements that aim to guard sure mental property rights (for occasion patents, copyrights and trademarks). Similarly, although agreements pertaining to the export of items are capable of being prohibited beneath competition legal guidelines outside India, they are unimpeachable under the Indian Act. The regulation will want to strengthen how these policies are to operate in practice (Nomani \& Rahman, 2013).

The remedies that can be ordered by means of the Commission in case of contravention of Section three (relating to anticompetitive agreements), has been provided in Section 27 of the Act. The Competition Commission of India (CCI) can enjoin an infringing party from persevering with or re-entering an illegal settlement and, in addition, impose upon such a birthday party fines not exceeding 10 percent of the common turnover for the last three monetary years. For any firm, such a sanction is considerable. The CCI can impose any different associated order or direction. In respect of cartels, sanctions are doubtlessly even greater severe The CCI may additionally impose on each cartel member a penalty for each 12 months of the cartel of up to three times its earnings or 10 percent of its turnover, whichever is higher (Nomani \& Rahman, 2013). 
Any contravention of the CCI's orders can entail imposition of further penalties, and ultimately, the CCI can file a complaint in opposition to contravention of its orders in the criminal court, which, in turn, may order additional fines and even a jail term up to three years.

The Act consists of a leniency programme, in the case of a cartel. The CCI will operate a leniency programme to companies that disclose evidence and statistics on cartels to the CCI beneath this programme can acquire decreased fines or keep away from fines altogether. It is worth noting that the leniency provision may also save the cooperating birthday celebration from a large penalty, but it does now not protect the party from a claim for compensation for loss or injury suffered through a character on account of the alleged violation by using the party, or from any different path or order of the Commission (Nomani \& Rahman, 2013).

The provisions of Competition Act (CA), 2002 dealing with abuse of dominance attract heavily from European Community (EC) jurisprudence on the topic and article 82 of the EC Treaty. Abuse of a dominant role via an enterprise or a group is also prohibited under the Act.

An organisation or team ought to evaluate whether it has a dominant position in the market, and whether it has abused its dominance. The key questions to be addressed are: (i) what is "dominant position;" and what kind of behavior constitutes "abuse of dominant position." (Nomani \& Rahman, 2013)

Dominant position refers to a role of strength wherein the company has won such a role in the market by means of way of large market share or in any other case that he is capable to play impartial of market forces. It refers to the position the player can manipulate the markets. The competition act no longer prohibits the dominant positions as was once the case in MRTP act but it prohibits the abuse of the same.

The Act beneath Section four (1) prohibits abuse of dominant position through any enterprise. The time period "dominant position" has been defined in the Explanation (a) under Section 4 (e) which states that the dominant function capability a position of strength, enjoyed through an enterprise, in the applicable market in India. Such a role permits a firm to function independently of competitive forces prevailing in the relevant market or affect its opponents or shoppers or the applicable market in its favor.

Dominance is now not incriminating on its own. A company holding such a position needs to have engaged in habits characterised as an abuse. In this regard, the Act incorporates an exhaustive list of potentially prohibited practices (Nomani \& Rahman, 2013).

According to the Section 4(2), abuse of dominance through an enterprise has been defined in the Competition Act to consist of at once or circuitously imposing unfair or discriminatory stipulations or prices in buy or sale of items or services; limiting or limiting production of goods and services, or the market, or limiting technical or scientific improvement touching on to goods or offerings to the prejudice of consumers; indulging in practices ensuing in denial of market access; or the usage of dominance in one market to pass into or guard different market. All the sanctions described in the case of anticompetitive agreements are available to the CCI towards abuse of dominance. If the CCI is blissful that there has been an abuse dominance, it may also difficulty a "cease and desist' order i.e. it can direct the organisation to desist from practices which constitute such abuse and impose a penalty of up to 10 percentage of the common turnover of closing three previous monetary years. In addition, the CCI can impose structural remedies. It can order division of a dominant firm with a view to make certain that the mission does no longer abuse its dominant position. It appears that such an order can be solely corrective, no longer pre-emptive, i.e., the CCI should pick out an ongoing abuse before ordering division of a 
dominant enterprise; however, the route in which the law will boost has to be watched (Nomani \& Rahman, 2013).

One of the biggest threat to competitions is the mergers and acquisition activities by using which the factors governing the opposition in the market are grabbed by a few or a single enterprise. But now not all the mixtures (mergers $\&$ acquisitions) are inside the purview of the Act, it specifies a restriction beyond which all to be approved by means of the competition commission to see the light of the day. The Act regulates the various forms of commercial enterprise mixtures and does not prohibit their formation.

Under the Act, "no man or woman or agency shall enter into a combination, in the structure of an acquisition, merger or amalgamation, which motives or is in all likelihood to propose a considerable damaging effect on opposition in the relevant market and such a mixture shall be void". But, all combinations are now not name for scrutiny unless the resulting mixture exceeds the threshold limits in phrases of property or turnover as targeted by way of the Competition Commission of India (Nomani and Rahman, 2013).

The Commission whilst regulating a "combination" shall think about some factors (genuine and viable import competition, barriers to entry, the diploma of market concentration; diploma of countervailing power in the market, the probability that the mixture would enable the parties to substantially and sustainably enlarge expenditures or income margins, the extent of probably positive competition, the extent to which substitutes are accessible or probable to be handy in the market, the market share, and the nature and extent of vertical integration in the market). The evaluation additionally consists of consideration of whether or not one of the corporations in the mixture is a failing enterprise and the nature and extent of innovation. In addition, the Commission should think about the possible benefits that would possibly waft from the mixture that would contribute to economic development and whether or not the benefits outweigh the unfavourable effects of the combination, if any (Nomani and Rahman, 2013).

The threshold limits varies according to whether the combination is by means of an organization or through a group, and additionally varies in accordance to whether or not employer or team has property or turnover only in India or has these worldwide. The threshold limits have been prescribed for the motive of aggregate under the Competition Act. The Act units a threshold beneath which a merger, acquisition or obtaining of control is no longer viewed as a mixture and is consequently backyard the merger regime of the Act The threshold is pretty excessive and is described in terms of assets or turnover (Nomani \& Rahman, 2013).

\section{Institutional aspects}

The administrative structure for the competition regime is coordinated by the Competition Commission of India.

The Commission was once established on 14th October, 2003 and commenced accepting cases according with the the Act after 1st September, 2009, is an expert body which functions as a regulator for preventing anti-competitive practices in the us of a and also has advisory and advocacy functions. CCI is a quasi-judicial and company body, having perpetual succession and a frequent seal with power to acquire, maintain and dispose of property, both movable and immovable and can contract in its personal name. In the discharge of its functions, the CCI shall be guided through the principles of justice, and has the strength to regulate its very own procedures. The commission consists of a chairperson and no longer much less than two and now no greater than six other participants appointed by means of central government. 
The Commission is vested with both regulatory and quasi-judicial powers to eliminate practices having an negative impact on competition, promote and preserve Competition, protect interests of consumers, and facilitate competition advocacy and unfold awareness (Nomani \& Rahman, 2013).

The Commission would no longer be hamstrung to act against cases of infringing conduct if situations come to its attention through any source, formal or informal. Further, the CCI can intervene successfully as it can direct any corporation or their association to discontinue their anticompetitive behavior and can demand the manufacturing of particular documents and records from an enterprise.

Thus, the CCI can make the fee of infraction high to deter such unlawful conduct. The CCI may, if it finds after enquiry that an settlement is anti-competitive, or that its motion constitutes abuse of dominance, pass an order directing the culprit to discontinue such settlement or abuse of dominant position. It may additionally impose such penalty as it may deem fit, which shall no longer exceed $10 \%$ of the average of the turnover for the ultimate three previous economic years, upon each of such persons or agencies that are parties to such agreements or abuse. If such an agreement has been entered into by way of a Cartel, the CCI may additionally impose upon the offending party a penalty up to three times its profits for every yr of the lifestyles of such agreement or $10 \%$ of its turnover for every yr of the lifestyles of the agreement, whichever is higher. The Commission can additionally issue instructions that such settlement shall be modified to the extent and in such manner as may also be specified. It can also additionally issue instructions to the concerned events for fee of fees and for obeying the orders as the Commission may additionally pass. The Commission may additionally additionally skip such different orders or issue such instructions as it might also deem fit (Nomani \& Rahman, 2013).

The Commission has been vested with the powers of a civil courtroom while making an attempt a suit, inclusive of the electricity to summon and examine any character on oath, requiring the discovery and production of archives and receiving proof on affidavits. To complement and supplement the area of the CCI in deciding and getting rid of anti aggressive practices, the Act especially prohibits civil courts to entertain any suit or intending which the Commission is empowered to determine. The jurisdiction of the Competition Act extends to all the sectors of the economy and region regulated with the aid of quarter unique laws. Hence inside the purview of the Act the CCI can make reference to a statutory authority or acquire reference from statutory authority. Further where in the direction of a intending before any statutory authority and trouble is raised through any birthday celebration that any decision which such statutory authority has taken or endorse to take, is or would be, contrary to any of the provisions of this Act, then such statutory authority can make a reference in appreciate of such problem to the commission. The statutory authority can also make the reference suo motu to the Commission. The CCI can omit closing order as well as intervening time order. However it can't overview its own order, it can only rectify it (Nomani and Rahman, 2013).

The decision of competition dispute is administered through appointment and function of the directorate of competition and appellate tribunal. The director regularly occurring (DG) is an investigation arm of the CCI in conducting inquiry into contravention of any provisions of the Act. This acts as watchdog and functions other functions as furnished with the aid of or below the Act. The director shall, when so directed by using the commission, aid the Commission investigating into any contravention of the provisions of this Act or any policies or regulations made thereunder. Although, the CCI is no longer bound by way of the findings in the record of the DG, it is obligatory for the CCI to refer the count for investigation to the DG and are searching for an investigation 
document as soon as it forms a prima facie opinion that a case of infringement of Section 3 or 4 has occurred.45 In case of enquiries into combination, the report from DG can also be referred to as upon through the CCI. The DG can also look at the conduct of related entities, of course, with the authorization from the CCI. The Additional, joint, Deputy and Assistant Director General or such officers or other employees so appointed shall work out his powers and discharge his functions, concern to the supervision and direction of the Director General (Nomani \& Rahman, 2013).

The Competition Appellate Tribunal (CAT) as an appellate mechanism hears all appeals in opposition to the order of the CCI. It is a quasi judicial body and consists of Chairperson and no longer than two different individuals appointed by way of Central Government. The CAT shall no longer be sure by means of the Code of Civil Procedure, 1908 but by using the principles of natural justice and any guidelines made by using the Central Government. However, CAT will have all the powers of a civil court. The lawsuits before CAT are deemed to be judicial proceedings. The attraction against the order of the CCI can be filed earlier than CAT (Nomani \& Rahman, 2013).

The CAT will hear and dispose of appeals against any route issued or decision made or order exceeded by way of the CCI and adjudicate claims for compensation and ignore orders for healing of compensation. The attraction can be filed with the aid of Central Government, State Government or enterprise or any character who is aggrieved by decision, course or order of CCI. Appeal should be filed within 60 days.

The tribunal will supply the possibility of hearing to different parties and then will skip the order. Copy of order will be dispatched to the parties to attraction and CCI. CAT can overview its personal decisions. In case of contraventions of CATS order without real looking grounds, punishment is imprisonment up to 3 years. Every order made by way of the CAT shall be enforced in the equal manner as if it were a decree of a courtroom in a suit. Appeal in opposition to CATS order can be made to Supreme Court within 60 days from the date of receipt of an order of the CAT (Nomani \& Rahman, 2013).

India is one of the closing foremost frequent regulation democracies to adopt the modernday competition law; therefore, it has the benefit of drawing persuasive values from matured jurisdictions (Pingali et al., 2016).

The Preamble of the Act offers an institutional context to the CCI. It states: An Act to provide, maintaining in view of the monetary development of the country. This is instead a special and unambiguous endorsement of the hyperlink between the micro functioning of individual markets and the larger improvement imperatives of the country.

Adopting an 'economic approach' to the application of opposition regulation offers a reasonably sound and capable framework for generating client welfare and financial efficiency (Pingali et al., 2016)).

\section{Comparative law aspects}

Indian competition law is a great deal younger than U.S. competition law (Pierce, 2017).

The fundamental statute that governs opposition regulation in the U.S., the Sherman Antitrust Act, was once enacted 77 years before India existed as an independent country. Development of competition law in India also was delayed with the aid of the lack of enthusiasm for a market-based economy that was once shared by most of the populace and political leadership of India for countless many years after India got its independence (Pierce, 2017).

The first Indian competition statute, the Monopolies and Restrictive Trade Practices Act of 1969, used to be replaced with the aid of the Competition Act of 2002 (CA). That statute prohibits 
any agreement "which causes oris likely to cause a considerable destructive impact on opposition inside India" (AAEC). Some agreements are presumed to have AAEC. They are unlawful except they can be shown to create effectivity gains. They correspond roughly to the sorts of agreements that stay problem to a certified per se prohibition in U.S. law - agreements to determine price, agreements to restrict supply, agreements to share a market, and agreements to have interaction in collusive bidding. Other kinds of agreements are unlawful solely if they can be established to have AAEC and they do not create efficiency gains. The statute also prohibits "abuse of dominant position."

The Competition Act also regulates mergers however those provisions did not go into impact until 2011. Large firms that advise to merge or to collect other giant firms have to notify the government in advance (Pierce, 2017).

The Competition Commission of India (CCI) consists of a Chair and two to 6 other members. They are appointed with the aid of the Central Government based on the tips of a committee consisting of the Chief Justice of India, the Secretary of the Ministry of Corporate Affairs, the Secretary of the Ministry of Law and Justice and two reputed experts. The Chair and the contributors serve a time period of 5 years and they can be removed through the central Government only for cause (Pierce, 2017).

The CCI has the electricity to decide that any practice violates the CA. It has the strength to ban any such exercise and to ban it on an intervening time groundwork throughout the duration in which it is investigating the practice. It can impose civil penalties and criminal penalties of up to three years in jail for violations of the CA. It has the equal powers as a civil courtroom and it has one-of-a-kind jurisdiction over disputes that arise under the CA. It additionally has the energy to determine its very own procedures (Pierce, 2017).

The Director General (DG) is the investigative arm of the CCI. The DG is appointed by means of the Central Government. The DG has a duty to investigate any alleged violation of the $\mathrm{CA}$ or the guidelines of the CCI when requested to do so through the CCI. At the give up of his investigation, the DG needed to issue a record that is now not binding on the CCI. The DG has many of the powers of a civil court, which include the energy to require the production of files and the strength to catch documents. The DG has the strength to issue orders, the violation of which can be punished by the CCI (Pierce, 2017).

The Competition Appellate Tribunal (COMPAT) has one-of-a-kind jurisdiction to hear appeals from choices of the CCI. It consists of a chair and two members who are appointed with the aid of the Central Government from a listing organized by using a determination committee. Members can be eliminated only for cause through the Central Government in session with the Chief Justice of India. COMPAT has the powers of a civil court and can challenge its very own rules of procedure (Pierce, 2017).

The Supreme Court of India has distinctive jurisdiction to hear appeals against decisions of COMPAT.

Private parties can supply information that can shape the basis for an inquiry by way of the $\mathrm{CCI}$ and can apply for compensation from the COMPAT based totally on the findings of the CCI or the orders of COMPAT. Notably, however, non-public events can not in reality provoke complaints to decide whether or not a firm has violated the CA (Pierce, 2017).

The primary factors of the Indian competition regulation regime are excellent. The statutes are drafted in methods that understand the want for the institutions to determine when a unique kind of habits is likely to produce horrific consequences on the overall performance of a market 
and when that identical type of habits is unlikely to produce terrible results and has as an alternative the practicable to produce socially desirable results (Pierce, 2017).

The simple factors of the Indian competition regulation regime are better than their U.S. counterparts in several important ways. First, unlike the Federal Trade Commission and Department Of Justice, the CCI has the electricity to trouble great guidelines to put into effect the CA. Second, in contrast to the U.S., India has avoided the threat that personal events will create awful criminal precedents by means of litigating cases earlier than courts of widespread jurisdiction whose judges lack the information required. Third, the Indian Competition Commission has the energy to decide its own rules of procedure. Used wisely, that strength lets in the Commission to adopt techniques that are sufficient to the task but do not produce the interminable delays that plague the choice making processes of the FTC and U.S. courts (Pierce, 2017).

India is developing an excellent competition regulation regime through taking simply a few vital steps.

First, and most important, India wants to pay a lot of interest to fantastic staffing of the institutions. The U.S. elevated its competition regulation regime dramatically when it delivered giant numbers of proficient economists to the FTC Bureau of Competition and the DOJ Antitrust Division and gave economists a predominant voice in the method of shaping and applying competition law (Pierce, 2017).

Second, India can keep away from the crippling delays in the U.S. competition regulation regime by using adopting rules of procedure that recognize that paper hearings are at least as appropriate as oral evidentiary hearings for functions of resolving the normal disputes that arise in proceedings earlier than competition law tribunals (Pierce, 2017).

Third, India can make good use of the CCI's electricity to difficulty policies by issuing rules that describe in element the way the CCI makes selections about whether a unique type of behavior violates the CA. situations.

Fourth, India must think about amending the CA to allow COMPAT to award treble damages to non-public parties who have been injured by means of violations of the CA as decided by using the CCI. The treble damage treatment in U.S. opposition regulation gives an effective deterrent to firms that are tempted to violate the competition laws (Pierce, 2017).

The Act does envisage a cartel leniency policy, which used to be added into force in August 2009 thru separate enforcing regulations. Full immunity from fines is accessible to the first birthday celebration to method the CCI with a 'vital disclosure' (meaning real and full disclosure) of data or proof ample to allow the CCI either to structure a prima facie opinion about the existence of the cartel, or to set up an infringement of section 3 - in every case in circumstances in which the CCI did now not already have enough evidence to make such a finding (Sansom \& Christian, 2010).

Although the regulations envisage the opportunity of making oral leniency applications, these ought to be observed with the aid of a written application, giving upward shove to issues as to the possible disclosability of such functions in foreign (particularly US) damages actions (Sansom \& Christian, 2010).

A dominant position is defined as a 'position of strength, enjoyed via an enterprise, in the relevant market, in India, which permits it to function independently of competitive forces prevailing in the applicable market, or to affect its opponents or buyers or the relevant market in its favour, a definition that corresponds nearly exactly to that underneath EC law other than in the probably extensive reference to affecting the relevant market in favour of the dominant enterprise (Sansom \& Christian, 2010). 
In identifying whether an business enterprise enjoys a dominant position, the CCI is required by using part 19(4) of the Act to have regard to thirteen listed factors. Ten of these are well known financial standards recognised in other opposition law systems, but there are additionally three standards referring to 'social responsibilities and social costs', 'relative advantage, via way of the contribution to the monetary development, with the aid of the corporation taking part in a dominant position' and 'any different component which the CCI might also think about relevant for the inquiry'. The effect of these provisions may be to absolve an otherwise dominant business enterprise from a discovering of dominance - and consequently legal responsibility for abuse of that dominance - on social, political, or economic development grounds (Sansom and Christian, 2010).

Most far-reaching is the provision under area 28 of the Act permitting the CCI to ruin up a dominant firm to make certain that it does no longer abuse its dominant position, besides requiring proof that it has already performed so. While this provision is possibly to be used rarely in practice, it offers upward push to professional issues as to the capacity of the CCI to penalise dominance per se, instead than only the abuse of that dominance.

Section 6 of the Act gives that "no character or company shall enter into a aggregate which reasons or is probably to cause an [AAEC] inside the relevant market in India and such a aggregate shall be void'. The introduction of a merger manage regime has been the most controversial phase of the Act in India, with Indian business hobbies retaining that Indian businesses need to have freedom to consolidate substantially in order to compete internationally. At the time of writing, the Indian government used to be persevering with to seek advice from with industry (on the groundwork of draft Combination Regulations) on both procedural problems and the timing of the introduction of the regime (Sansom \& Christian, 2010).

The Act defines a 'combination' as an acquisition of shares, voting rights, assets, or management in which the combined property or turnover of the parties exceed positive thresholds. Although separate thresholds are given for 'group' and 'non-group' combinations, the wide definition of the former class ability means that its thresholds will apply in nearly each case. Those thresholds are blended properties of INR30,000 million (roughly E420 million) or blended turnover of INR120,000 million (roughly E1,700 million). Where either or both corporations have property or turnover outdoor of India, the thresholds are combined property of US\$2,000 million, together with at least INR5,000 million (roughly E70 million) in India, or blended turnover of US\$6,000 million, such as at least INR15,000 million (roughly E210 million) in India. Although these thresholds may want to be met when only the corporation being obtained has property or turnover in India, the draft Combination Regulations provide that combinations where at least two events to the aggregate do not have property of INR 2,000 million (roughly E28 million) in India, or turnover of INR6,000 million (roughly E85 million) in India, will be deemed not going to supply upward shove to an AAEC (Sansom and Christian, 2010).

Notification of qualifying mergers is obligatory and no such merger can come into effect till the expiry of 210 days (a lengthy length through worldwide standards) or CCI clearance, whichever is sooner. It is currently envisaged that this length will incorporate a 30-day segment I inquiry for cases raising no or solely minor issues; a 60-day section I duration for combos raising more noticeable issues, and the remainder of the 210 day period for designated investigation of combos which show up prima facie to supply upward shove to an AAEC (Sansom and Christian, 2010).

The assessment of whether or now not a mixture is possibly to reason an AAEC involves consideration of a range of trendy monetary indicia listed in area 20(4) of the Act, which explicitly 
consist of both failing association and efficiencies defences. As with the evaluation of dominance in section four cases, however, the evaluation of an AAEC in merger instances additionally consists of reference to the 'economic development' criterion.

It is doubtful how frequently this provision will be relied on in exercise to clear mergers that are probable to lead to an AAEC (Sansom \& Christian, 2010).

\section{Conclusions}

In re-adapting its competition laws, the Indian government selected to undertake a competition enforcement regime stimulated by the laws that have matured within developed nations.

The Competition Act borrows statutory language from competition law in the western world and thus benefits from the evolution of antitrust enforcement that has taken place over the last century. But while the Commission's beginning factor is an amalgamation of Western competition law, its enforcement has been unique. India ought to continue to strengthen enforcement priorities and interpret its guiding statute in a way that is congruent with its special economic situation.

The Commission has chosen to depart from US and EU antitrust jurisprudence in some aspects. While I have criticized its abuse of dominance analysis, some might also argue that the. The Commission's heavy scrutiny of conduct by way of dominant entities is sensible. The Commission may wish to ensure that dominant corporations are no longer the usage of their strength and leverage to exclude smaller firms. An enforcement regime that handicaps dominant firms in order to protect competitors (who are likely to be smaller start-up firms) departs from the U.S. model but may promote financial mobility.

The Commission will harm India's market competitiveness if it punishes efficiency. This could cripple essential industries and harm the global competitiveness of its strongest sectors.

Only the future will show us if the Commission will be able or not to move between these objectives.

\section{References}

Gupta, P. (2019). Competition Laws in India An Overview, Kochhar \& Company, 3-11.

Nomani, Z., M., \& Rahman, F. (2013). Regulation of Anti-Competitive Practices and Trade Secret Laws under Competition Legislation of India: A Paradigmatic Analysis, Researchgate, January, 3-11.

Pierce, Jr, R., J. (2017). Comparing the Competition Law Regimes of the United States and India, GWU Law School Public Law Research Paper No. 2017-27, GWU Legal Studies Research Paper No. 2017-27, 14-18.

Pingali, V., \& Chaudhuri, M., K., \& Malik, P., \& Tamara, R., \& Kakkar, A., \& Chatterjee, C., \& Mondal, S., \& Sokol, D. (2016). Competition Law in India: Perspectives, The Journal for Decision Makers 41(2), Indian Institute of Management, Ahmedabad SAGE Publications, 168-193.

Sansom, M., \& Christian, P. (2010). India's New Competition Regime: The Elephant Who Became a Tiger, Journal of European Competition Law \& Practice, 2010, 1(1), 62-66.

Singh, P., Lohiya, R.M. (2018). Competition policy and law vis-à-vis consumer welfare, International Journal of Law, 4(5), September 2018, 18-24. 